\title{
OVERINDULGENCE: THE NEMESIS OF HAPPINESS
}

George Abaunza*

\begin{abstract}
RESUMO - O artigo enfoca algumas das características da superproteção e extrema indulgência dos pais com relação aos filhos. Recorrendo a filósofos da educação, tais como Locke, Rousseau e Dewey, serão expostos os efeitos corrosivos de uma indulgência excessiva sobre o potencial de felicidade nos filhos, assim como naqueles que compartilham o mesmo espaço social. Como esses autores já o mostraram, os pais que se excedem em indulgência terminam fomentando expectativas em seus filhos para além de suas reais capacidades ou atropelando a sua iniciativa ao usurpar a sua independência. Em ambos os casos, os pais podam a autonomia de seus filhos e prejudicam o trabalho necessário ao desenvolvimento de hábitos e disposições para planejar e realizar projetos exequíveis que são fundamentais para uma felicidade sustentada e duradoura. Para simplificar, na medida em que impede o desenvolvimento de aptidões para alcançar a felicidade e desenvolver um senso de responsabilidade social, a superproteção e a indulgência excessiva se tornam uma forma disfarçada de abuso infantil.
\end{abstract}

PALAVRAS-CHAVE - Autonomia. Desenvolvimento. Felicidade. Filosofia da educação. Responsabilidade social. Superproteção.

\begin{abstract}
This article brings to light some of the characteristics of the pervasive parental overpermissiveness and hyper-protectionism that unfortunately have made their way into our culture. With the aid of philosophers of education, such as Locke, Rousseau, and Dewey, I expose the corrosive effects that parental overindulgence has on the potential happiness of those in their charge, as well as on those who share their social space. As these philosophers warned long ago, by overindulging their desires, parents either overextend their children's expectations well beyond the reality of their capabilities or they squash their initiative by usurping their independence. In either case, parents cripple their children's autonomy and thereby detract from the real work needed to develop habits and dispositions necessary to plan and carry out achievable accomplishments that are integral for sustained and enduring happiness. Put more simply, overindulgence, to the extent this impedes the development of requisite skills for achieving happiness and developing a sense of social responsibility, becomes a disguised form of child abuse.
\end{abstract}

KEY WORDS - Autonomy. Development. Happiness. Overindulgence. Philosophy of education. Social responsibility.

It is not in the guise of a hideous monster, with horns and tail, that Satan tempts the children of mankind,

but as an angel of light.

(Henry George, 1929)

We are, each of us, separate human beings who stand alone within a world that simultaneously acts upon and demands action from us. This world,

Assistant Professor, Department of Philosophy, Felician College, NJ.

\begin{tabular}{|l|l|l|l|l|l|}
\hline VERITAS & Porto Alegre & v. 54 & n. 1 & p. 69-88 & jan./abr. 2009 \\
\hline
\end{tabular}


to the extent it is external to us and yet part of us, must be dealt with one way or another. The one thing we cannot accept is to do nothing. So, what should we do? Beyond mere survival, ideally we seek happiness; we initiate activity, create, and thus attempt to meaningfully forge our way through life. But seeking happiness, let alone finding it, is no easy task, and perhaps the most difficult of all. Yet, it is quite possibly the most rewarding of human endeavors. How we find this elusive happiness has a lot to do with our relationship to an environment permeated with people, things, and forces, with which we as individuals must necessarily enter into relations.

Indulge me in the following three assumptions. First, that happiness is essential to human wellbeing. Second, that happiness - achieved in part by an ability to set and realize reasonable goals and expectations - is made palpable through a sense of accomplishment. This second assumption further implies a significant degree of independence, in order to a) formulate our own expectations based on our personal understanding of our capabilities, and b) to exercise our ability to learn from both our successes and failures. In other words, happiness requires that an individual be capable of intelligently directing her own life, and be able to do so with full autonomy, that is, as a self-directing individual who is able to define, assess, and realize her own goals.

At the same time, the liberty with which one directs one's actions must in certain respects be kept in check, so as to render such autonomy amenable to not only the satisfaction of those ends circumscribed by the needs of said individual, but also to serve the interests of satisfying generally those concerns that define the social welfare of one's society. This brings me to my third assumption; that achieving happiness is neither simple nor easy, nor is it a purely individual matter. It requires the training and honing of specific capabilities, along with a social sensibility, that together allow one to formulate reasonable expectations, especially in an environment of affluence and false needs. Among these capabilities is the self-directing wherewithal by means of which to discern one's realistic place and needs within such a powerfully influential scheme.

The unfortunate conclusion I shall draw from these assumptions is not one that resolves the issue, but rather one that at least exposes the corrosive effects that parental overindulgence has on the potential happiness of those in their charge, as well as on those who share their social space. By overindulging their children's desires, parents either overextend their expectations well beyond the reality of their children's capabilities (over-permissiveness) or they squash their initiative by usurping their independence (hyper-protectionism). Such overextensions, in either direction, serve to establish a sense of entitlement to unreasonable demands, a false sense of hope, and a crippling of autonomy that together detract from the real work needed to develop habits and dispositions necessary to plan and carry out achievable accomplishments that are integral for sustained and enduring happiness. Put more simply, overindulgence, to the extent this impedes the development of requisite skills for 
achieving happiness and developing a sense of social responsibility, is tantamount to a disguised form of child abuse.

\section{Signs of our times}

We have certainly come a long way since our days as hunter-gatherers. Zone Chefs, a food service company in New York City, offers three fully cooked meals delivered each morning to your home. "All you have to do," their radio advertisement urges, "is open your door." Our ancestors would find this truly magical. But today this does not surprise us, given the levels of relative affluence we enjoy, which allow so many of us to bear more easily the twin luxuries of idleness and complacence..."and for an additional 304," the digitalized phone-operator voice persuades, "that number can be automatically dialed for you."

Apparently, also gone are the days when children needed to draw connections between their education and survival. ${ }^{1}$ Given the creature comforts of many living in contemporary societies such as the United States, many of our young may no longer find themselves confronted with the ruthlessness of a bygone primitive state. Nonetheless, they are faced with new challenges and threats to their survival. Among these are depression, anxiety, obesity, unwanted pregnancies, drug addiction, violence, emotional apathy and, ironically, the very nurturance that, in attempts to shield them from peril, only further threatens their wellbeing by prolonging their dependence on others. Lost, alongside this imposed vulnerability, are the virtues of perseverance, self-discipline, self-motivation, and self-reliance.

It is within this contemporary context that we find the redeeming value of the many philosophical exhortations to develop and never relinquish our personal responsibility in the pursuit of happiness. Reaching happiness, JeanJacques Rousseau recommends, is only possible when we cease to reach beyond our selves, that is, when we cease to define our selves in relation to unnecessary desires or simply learn to desire only what is necessary. But, today, this is easier said than done. That the desire for things seems to far exceed their affordability is easily forgotten within a culture where gratification and status are purchased on credit.

\footnotetext{
William Glasser, in his Choice Theory in the Classroom. New York: Harper Collins Pub. Inc. [1986] (1988) notices the shift after World War II, from an educational culture that connected learning with survival to one that replaced this with a concern for acceptance (pp. 66-7).

A quick look at our credit mania speaks volumes. Americans carry over $\$ 680$ billion in revolving credit. Finance charges Americans paid in 2001 reached $\$ 50$ billion and currently exceed $\$ 65$ billion annually. American Consumer Credit Counseling (http://www.consumercredit.com/docs/BudgetingWebpdf.pdf). Other figures show that 10\% of cardholders had card balances in excess of $\$ 10,000$. More than a third (36\%) of those who owe more than $\$ 10,000$ on their cards have household incomes under $\$ 50,000$. And $13 \%$ who owe that much have household incomes under $\$ 30,000$. MSN Money Magazine (http://moneycentral.msn.com/content/Banking/creditcardsmarts/P74808.asp).
} 
Comparing a "natural" to a "civilized" state of affairs, Rousseau writes: "In fact, the real source of all those differences is that the savage lives within himself; whereas civilized man, constantly outside himself, knows only how to live in the opinion of others; and it is merely from their judgment of him that he derives the consciousness of his own existence." ${ }^{3}$ Philosopher Alain de Botton likewise argues that in the modern world, "The attentions of others matter to us because we are afflicted by a congenital uncertainty as to our own value, as a result of which affliction we tend to allow others' appraisals to play a determining role in how we see ourselves; our sense of identity is held captive by the judgments of those we live among." "As if this dependence were not enough, a consumption-driven democracy introduces a shared discomfort and disease that no longer comes from the threat of scarcity, but instead now comes from the self-inflicted pressure to keep our desires in pace with the empty promise that all of us may equally attain the same things. De Botton chronicles this social malady, which he euphemistically labels 'status anxiety':

Insofar as advanced societies supply their members with historically elevated incomes, they appear to make us wealthier. But in truth, their net effect may be to impoverish us, because by fostering unlimited expectations, they keep open permanent gaps between what we want and what we can afford, between who we might be and who we really are. The price we have paid for expecting to be so much more than our ancestors is a perpetual anxiety that we are far from being all we might be. ${ }^{5}$

Because we assign a saleable price to all things - within a system of presumably free exchanges - everything is believed to be within our reach. Even those things we cannot reach because we lack the real means by which to do so. De Botton, who credits Rousseau for bringing this 'status anxiety' to our attention, suggests that with the greater availability of commercial goods appropriately dubbed 'objects of desire' within a culture driven by consumption - there is an expansion of desire. Keeping pace with what we are, at least in principle, able to attain or what we convince ourselves is within our grasp, gives us something new to worry about-"A worry so pernicious as to be capable of ruining extended stretches of our lives; that we are in danger of failing to conform to the ideals of success laid down by our society."

Interestingly enough, even Plato's criticism of democracy proves to be quite prophetic. The irresponsibility on the part of parents who neglect to educate their children in matters of virtue generates a recipe for the debacle that is democracy. Greed, coupled with luxury, promotes physical and intellectual laziness, and diminishes all moral incentive for exercising rational self-

\footnotetext{
Rousseau (1967), p. 245 (emphasis mine).

De Botton (2004), p. 8.

Ibid. pp. 43-44

Ibid. pp. vii-viii.
} 
control in the service of mutual social interests. This opens the door to extravagant desires which, "in the end, seize the citadel of the young child's soul, finding it empty and unoccupied by studies and honorable pursuits and true discourses." When democracy is viewed as nothing more than a great equalizer, as equal powers and freedoms are granted to all and where all desires and pleasures carry equal weight, moral chaos ensues. Plato warns of how the demos "euphemistically denominate insolence 'good breeding,' license 'liberty,' prodigality 'magnificence,' and shamelessness 'manly spirit'." 8 The democratic individual pursues pleasure for pleasure's sake and, therefore, does not discern between what is beneficial and potentially harmful.

Such is Plato's democratic individual: selfish, greedy, irrational, and intemperate. Lacking the rational ability and, therefore, the temperance to make decisions that benefit even themselves, such selfish democrats cannot exercise the self-control needed to consider the interests of others, let alone empathize with them. A diminished capacity for rationality and self-control can have dire consequences within any system of social organization, let alone one that must rely so heavily on the deliberations of its citizenry. Add to the mix a radical individualism that renders people unwilling, if not outright incapable of respect and empathy toward others - both essential requirements for achieving a democratic way of life. A citizenry that lacks the requisite intelligence and self-discipline to make decisions for their own welfare and that of their society ought not to be entrusted with the power to make such decisions. ${ }^{9}$

Whereas the exigencies delineated by our physical and environmental constraints might normally be enough to check the limits of our freedoms, thresholds of autonomy are now calibrated according to a free-market of incoherent desires and the superficialities of unsubstantiated capabilities. Advertisements continually promise us that we can "have it all." But what exactly are the implications of "having it all?" I'm not quite sure. Nor do I think people, including parents, bother to consider what such a proposition entails. To begin with, what would I do with "it all?" Where would I put it? Unable to realistically accomplish or acquire everything, the freedom to everything at our disposal is just as daunting as that giant boulder God is able to create, yet we question if even $\mathrm{He}$ is able to raise. What is more, a democracy narrowly conceived in terms of an economic equal opportunity to all things has its effectiveness measured by its ability to service mass

\footnotetext{
Plato (1994), Book VIII (560c), p. 788.

Ibid. (561a), p. 789.

Cultural critic Neil Postman addresses the impact of media on our society in several works, among these: The Disappearance of Childhood. New York: Vintage Books [1982] (1994); Amusing Ourselves to Death: Public Discourse in the Age of Show Business. New York: Penguin Books (1985); and, Technopoly: The Surrender of Culture to Technology. New York: Vintage Books (1993). Because television makes no complex demands on either the mind or behavior, this poses serious implications for democracy. According to Postman, "We do know that the capacity of the young to achieve 'grade level' competence in reading and writing is declining. And we also know that their ability to reason and to make valid inferences is declining as well" (Cf. 1994, p. 132).
} 
consumption. In affluent societies such as ours, this mass interest appears as a leveling of heightened tastes - everyone wanting the best, most, and most expensive - which, in turn, serves to supplant the autonomy of the discriminating consumer. A democracy that merely eulogizes autonomy by propagandizing an irresponsibly exaggerated equality, along with its false sense of entitlement, upstages the need for informed consent and satisfaction of real and realistic needs; it is as empty as the veritable Platonic cave in which we find ourselves thrilled - like children who know no better - by the illusory honors we bestow upon one another.

\section{Imbalance - The Nemesis}

A great mistake made in the pursuit of personal fulfillment is allowing one's desire to exceed one's power to realize what one desires. As Rousseau sees it, "A being endowed with senses whose faculties [powers] equaled his desires would be an absolutely happy being," as far as "it is in diminishing the excess of the desires over the faculties and putting power and will in perfect equality" that true happiness consists. ${ }^{10}$ Since one day Emile shall reach adulthood, in order to think for himself, be his own person, and find what truly fulfills him, he requires a disposition shaped by necessity, rather than the opinions of others. If we are not careful to balance our actual capabilities with our true needs, we continue to encourage the kinds of gratuitous excesses that belie the very nature of what we intend by satisfaction. The pernicious anxiety - ironically, born of abundance - arises from our inability to limit our wants. De Botton writes, "There are two ways to make a man richer, reasoned Rousseau: give him more money or curb his desires. Modern societies have done the former spectacularly well, but by continuously whetting appetites they have at the same time managed to negate a share of their success." ${ }^{11}$

Since "the truly free [person] wants only what he can do," ${ }^{12}$ a selfregulating form of freedom becomes vital for determining what we desire and establishing within ourselves the very capability by means of which we achieve or acquire what we desire. It is the balance of our capability with reasonable desire that ought to calibrate the barometer of our self-restraint. Simply stated, Rousseau recommends that what is necessary for the exercise of real freedom is that we balance the ambition of our goals with our ability to bring said goals to fruition. The individual able to exercise self-control in this manner is happiest, since she is less prone to disappointment, so long as she does not desire or will more than is necessary, or more than she is capable of attaining. In other words, prone to this more realistic approach, she tends towards a more effective means of dealing with the possible disappointment

\footnotetext{
Rousseau (1979), p. 80.

De Botton (2004), p. 43.

Rousseau (1979), p. 84.
} 
that comes from an inability to realize her happiness due to either a deficient desire to match her power, or insufficient power to catch up to her desire.

The imbalance of capability and desire plays out in our culture more simply. Translated, it refers to the distance we create between our realistic capabilities - what we have the power to realize - and our expectations. Hence, the idea is not to deny ourselves expectations; rather, it is to construct these in step with our real potential to succeed in our accomplishment of these. One ought to continually raise expectations and desires, so long as one's capabilities keep pace. One might also deliberately establish expectations just beyond one's capabilities, so as to test and challenge the latter. This is precisely what we do when we challenge our habits and stretch these towards new understanding and ability. Yet, maintaining reasonable expectations, again, helps to ensure the prospect of accomplishment. And, we might add to this, because our accomplishments arise from our true capabilities, we give substance to accomplishments thus earned.

The imbalance plays out in an interesting manner when it comes to the overindulged child. There is a simultaneous increase and diminution of both capability and desire. By appeasing the whims of children, we increase their thresholds of desire while we diminish their capability. In other words, by having things literally handed to children and constantly agreeing to their demands, we neither develop their powers, nor do we provide a realistic basis for dealing with inevitable frustrations. The imbalance occurs in the other direction as well, towards an apparent increase in power, since when children are indulged they are, in a skewed sense, being empowered. This false, though effective sense of empowerment - power over their caregivers - because it results in having things done for them, works to diminish their personal ambition. Children become complacent. And certainly desires or expectations that do not arise from one's own intelligent assessment of personal needs are, in essence, unrealistic, not to mention inauthentic.

Unable to remove frustrations and tackle adversities on one's own diminishes one's power and desire to overcome these. Just as one's capability and desire for learning to swim are strongly and immediately motivated once dropped into the deep end of the swimming pool, never knowing obstacles, one never truly understands the implications of imminent challenges, nor the necessity of finding personal ways of dealing with these. Rousseau admonishes, "Far from being attentive to protecting Emile from injury, I would be most distressed if he were never hurt and grew up without knowing pain. To suffer is the first thing he ought to learn and the thing he will most need to know." ${ }^{13}$ More easily said, we learn better to balance by experiencing the imbalance early on and bear the onslaught of adversities, difficulties, and frustrations, just as much as we gain from our victories, which are only possible

13 Ibid. p. 78. 
when we traverse the terrain of what lies before us. Might we not learn about adversities and their concomitant victories, that is, successes, and, just as importantly, learn how to relate to these, from our earliest exposures to deliberately engineered and purposely crafted limits? Might this not be what we refer to as 'learning' itself?

\section{In our caregivers' hands}

This is not to say that parents are entirely responsible for either overindulgence or unhappiness, especially within an economic culture that forges its very identity by inventing and propagating artificial desires, and then cleverly turns these into unnecessary needs. But, making specific reference to parental responsibility, Rousseau warned of how overindulging the child causes us to step "outside of nature...when [a mother] makes an idol of her child; when she increases and nurses his weakness in order to prevent him from feeling it-a barbarous precaution." ${ }^{14}$ Overindulgence in the forms of both overpermissiveness and hyper-protectionism are at the forefront in current child rearing literature. Psychologists and educators alike, from television programs to periodicals and books, are grappling with the problems brought on by spoiling. Among these, child psychologist Dan Kindlon points to several related conditions afflicting today's overindulged children, including: selfcenteredness, lack of motivation, obesity, and various other problems linked to an inability to exercise self-restraint. ${ }^{15}$

Parents who believe they are providing love to their children by constantly doing for them, accommodating their every desire and whim, and clearing all frustrations from their paths, are in actuality creating greater difficulties for them in the future. When anyone acts always on our behalf, we do not - nay we cannot learn to do for ourselves. Almost a hundred years before Rousseau, John Locke warned that "parents, by humoring and pampering them when little, corrupt the principles of nature in their children, and wonder afterwards to taste the bitter waters, when they themselves have poisoned the fountain." ${ }^{16}$ Locke adds to these corruptions - "those ill humors which [parents] themselves infused and fomented in their [children]" - the emphasis placed on

\footnotetext{
14 Ibid. p. 47.

15 Among the myriad recent sources, see: Hara Estroff Marano, A Nation of Wimps: The High Cost of Invasive Parenting. New York: Broadway Books (2008), originally "A Nation of Wimps," Psychology Today (November/December 2004), pp. 58-70; Michael Osit, Generation Text: Raising Well-Adjusted Kids in an Age of Instant Everything. New York: Amacom (2008); Peter N. Stearns, Anxious Parents: A Modern History of Childrearing in America. New York: New York University Press (2004); Robert Shaw, The Epidemic: The Rot of American Culture, Absentee and Permissive Parenting, and the Resultant Plague of Joyless, Selfish Children. New York: Regan Books-Harper Collins (2003); Dan Kindlon, Too Much of a Good Thing: Raising Children of Character in an Indulgent Age. New York: Hyperion (2003); Diane Ehrensaft, Spoiling Childhood: How Well-Meaning Parents Are Giving Their Children Too much - But Not What They Need. New York: Guilford Publications (1997); Carol Lynn Mithers, "The Perils of the Pushover Parent," Ladies Home Journal (January 2003), pp. 92-7.

${ }_{16}$ Locke (1947), p. 230.
} 
the clothing and outward appearance of their children, as well as an overindulgence in food and drink that becomes the wealthy and intemperate. Today we witness these corruptions manifested, respectively, in the exorbitant purchasing power bestowed upon adolescents, the high incidence of obesity at a young age, and binge drinking on college campuses.

We can find behind these self-destructive behaviors, and their respective dispositions, parents who take it upon themselves to exaggerate the thresholds of desire and appetite in their young. A problem even in Locke's day, he counseled that "contrary to the ordinary way...the first thing [children] should learn to know, should be that they were not to have anything because it pleased, but because it was thought fit for them." ${ }^{17}$ Ill equipped to make appropriate decisions for themselves, children inevitably follow the lead of their parents. But, it appears, many parents have lost touch with their children's real needs - not an improbable result of living within a society tailored to accommodate every desire. ${ }^{18}$ Spoiling is bound to be especially pernicious within a culture permeated by mass-marketed goods. Under these circumstances, artificial desires condition adult and young alike to rely on extrinsic and material forms of motivation.

The sheer pervasiveness of such potential rewards makes exercising selfrestraint a daunting task even for parents, who, through their example - for better or worse - shape the desires of their young. The ubiquity of material rewards overwhelms parents, who then put into practice the ill-conceived principle that children's needs are best regarded by providing indiscriminately for their desires. When parents give in to their children's every desire, they end up reversing the order of authority in the home. Instead of parents taking the lead in the development of their children's habits and establishing in them reasonable thresholds of desire, they try to befriend their children early on, and only later discipline them when it is too late.

Now, consider happiness - something sages from time immemorial have suggested is found within. Yet, for various reasons, we continue to convince our young and ourselves that it is things outside ourselves that bring us happiness. As might be expected in a society that democratizes consumption, the pitiable proposition - that it is things that make our lives meaningful and, therefore, worth living - would have to follow from such an assumption. We thus learn to rely on things external when seeking fulfillment, leading to other false sources of happiness, such as the pursuit of power, the desire for fame, and solace in narcotics, pharmaceuticals, alcohol, and other self-destructive addictions. Perhaps the greatest travesty connected to this conception of our

\footnotetext{
Ibid. p. 234.

${ }_{18}$ For an interesting and statistic-filled report on the consumer habits of Americans and an account of "marketing's negative effects on children's physical, psychological, and social well-being", see (Cf. p. 34) Arthur Asa Berger, Shop "Til You Drop: Consumer Behavior and American Culture. Lanham, MD: Rowman \& Littlefield Pub. Inc. (2005).
} 
relation to things external is that we seek these, or avoid them once they cause direct harm, in place of the happiness we originally set out to experience.

Such is the self who lives life in hopes that the world will conform to it, and brandish upon it ready-made gifts of happiness and fulfillment neatly packaged as objects. Meanwhile, this distraction with things keeps us from helping the young develop those difficult skills needed to realize their own happiness; and so we instill in them the desire for things, rather than a desire for a more authentic source of fulfillment. Through example, we instill in our young the want for things, which we shamelessly pass off as the need of things. Thus we concede our happiness, fulfillment, and even our freedom, to the pursuit and valuing of external rewards and projection of unreasonable expectations. To be clear, this is not an attempt to promote some sort of prudish asceticism, according to which we ought to deny children entirely the pleasures of rewards. Rather, it is to propose that the very possibility of conceiving that happiness lies within our own capabilities has its chances diminished in a world so full of things, until individuals become capable of understanding that what motivates us to seek happiness is also situated within.

Coupled with this awareness, there is a need for a palpable sense of freedom that is crucial to our development. Rousseau envisions our passion for survival as a natural and necessary impetus for learning and the desire to continue learning. Threats against our survival make present to us the need to exercise personal power. The need to secure our survival summons our first and most basic expressions of free action and initiative. The necessities of survival are our first great teachers in the lessons about the process of learning itself - something we must ultimately be motivated to do for ourselves. We recognize in Emile fervor for personal sovereignty and a kind of striving towards self-actualization that counters those social forces that too often stifle individuality and personal responsibility.

John Dewey, speaking in Rousseauian terms, stresses the importance of liberty in our pursuits. "Liberty for the child" he writes, "is the chance to test all impulses and tendencies on the world of things and people in which he finds himself," so that "consequently he becomes acquainted with his world and also learns the use and limits of his own powers."19 Autonomy is essential for moving from an externally imposed to an internally constituted form of selfcontrol. Only the latter places the onus squarely on the individual. The selfmotivation driving our choices is coupled with self-evaluation, which, in turn, incites us to take responsibility for our actions and personally fashion the standards by which we will to live our lives. ${ }^{20}$ The choice as to which form of

\footnotetext{
19 Dewey (1915), pp. 297, 215.

${ }^{20}$ Amy Norton, in "Self-confident children may be healthier as adults" Psychosomatic Medicine (May 2008), reports on favorable health effects of those who demonstrate an "internal locus of control" (i.e., "individuals [who] think they can influence events through their own actions."
} 
control shall win the day remains in the hands of caregivers. But this requires us to put our trust in the benevolence of others, in the hopes that our freedom is neither too severely limited nor, what is just as serious, that we be fooled into believing that we are freer than we really are simply because we are able to do what we please or purchase what we like. We may, on the other hand, opt for the kind of control that is harvested within - self-control commensurate with a freedom so personal that, ironically, only the selfish fool would relinquish.

Here, at least two salient points may be drawn from Rousseau's emphasis on age-appropriate learning. ${ }^{21}$ The first has to do with the fact that more and more parents today are forcing their children's development by rushing it. Resulting in what Rousseau would describe as a "barbarous education, which sacrifices the present to an uncertain future that burdens a child with chains of every sort and begins by making him miserable in order to prepare him from afar for I know not what pretended happiness which it is to be believed he may never enjoy." 22 Dewey expands further on Rousseau's sentiment, by connecting the need to respect children with the kind of careful attention that ought to be given to the process of their development. He writes, "Reverence for childhood is identical with reverence for the needs and opportunities of growth. Our tragic error is that we are so anxious for the results of growth that we neglect the process of growing." ${ }^{23}$

Gene R. Carter, Executive Director of the Association for Supervision and Curriculum Development (ASCD), places Rousseau's ideas within a contemporary context by proposing that, "a comprehensive approach to learning must recognize that successful young people are knowledgeable, emotionally and physically healthy, motivated, civically inspired, prepared for work, selfsufficient, and ready for the world beyond their own borders." ${ }^{24}$ Carter goes on

${ }^{21}$ According to Rousseau's own admission, his "whole book is only a constant proof of this fundamental principle of education" — that Emile should not learn anything before that stage in which, in due time, his capabilities may sustain such lessons. Rousseau, (1979), p. 178.

22 Ibid. p. 79. During the time in which he writes Emile, Rousseau claims that approximately half of all children do not live beyond the age of eight.

23 Dewey, (1915), p. 213. During Emile's second stage of development-the age of nature-Rousseau admonishes the tutor to "love childhood." Despite Rousseau's reminder that, "Nature wants children to be children before being men" (Op. cit., 1979, p. 90), current titles by educators and psychologists alike, such as: David Elkind, The Hurried Child: Growing Up Too Fast Too Soon (3 ${ }^{\text {rd }}$ ed.). Philadelphia: Perseus Publishing (2001); William Crane, Reclaiming Childhood: Letting Children Be Children in Our Achievement-Oriented Society. New York: Henry Holt (2003), indicate an awareness of the increased pressure being placed on children in preparation for skills and knowledge that they may be too young to comprehend. Newspaper articles also reveal disturbing trends. For instance, Rita Giordano reports that, "In this age of anxiety over tougher college admissions and schools labeled as failing under No Child Left Behind (NCLB), more parents are seeking to raise the bar for children at ever-younger ages." See Rita Giordano, "Too Young for Tests - But Not for Tutors," The Philadelphia Enquirer, May 31, 2005. Witness the transformation of Froebel's kindergarten into today's full day "kinder-grind." See, Amy Dickinson, "Kinder Grind," Time, November 8, 1999, p. 61.

24 Gene R. Carter, "A Vision for Public Schools: Academics Is Not Enough," ASCD, http://www.ascd.org/portal/site/ascd/menuitem, retrieved May 2005. 
to cite a comprehensive report on the positive effects of promoting ethics in the high school ranks, in which eight specific strengths of character are outlined in efforts to help alleviate the moral morass in our schools. Interestingly enough, we see many of the educational outcomes proposed by Rousseau for Emile reflected in this report. Included among these are: becoming "socially and emotionally adept; self-disciplined; personally responsible moral agents; and contributing members of a democratic community." ${ }^{25}$ But how could the irresponsible overindulgence in the instruction of our children ever produce such virtues?

And so, we find ourselves in the midst of an interesting tension - a veritable contradiction - between the delicate pampering and overindulgence with which parents buffer their children's errors on the one hand, and the unforgiving harshness and precision with which we extort their innocence. Children are being incapacitated socially, while simultaneously being hurried academically and athletically. ${ }^{26}$ What may appear as two separate problems - overindulging and pushing children into adulthood - is really the same two-headed hydra of continued dependence, which, again, impedes the development of skills necessary for the pursuit of happiness.

On the one side, there is the dependence created by the overindulgence of desires, to which dependence children become addicted, and thus enslaved. On the other side, there is the dependence wrought by the exorbitant expectations exacted on their developing imaginations, so that their lack in power and preparation leaves them dumbfounded at the site of their failures. Rather than equip our young with more effective means for survival, we abandon them to their instincts and leave them no resort other than to survive with the aid of what limited skills they may happen to possess at their particular stage of development. And survive they shall, though at times resorting to a kind of apathy that shelters them from an extra-subjective existence, or by means of the video games that facilitate their indifference that train them in the art of not caring or in not having to understand why they might care.

\section{Educating the democratic animal}

Dewey further expands on Rousseau's sentiments with the idea that considering the infant's needs does not entail relinquishing authority over her. As

\footnotetext{
${ }^{25}$ See, Tom Lickona and Matt Davidson. Smart \& Good High Schools: Integrating Excellence and Ethics for Success in School, Work, and Beyond. Cortland, N.Y.: Center for the 4th and 5th R's (Respect \& Responsibility)/Washington, D.C.: Character Education Partnership (2005). www.cortland.edu/character/highschool, retrieved May 2008.

${ }^{26}$ Little-league baseball players are having surgeries to repair their overused arms as parents and coaches force these children to play in an inordinate number of games and throw pitches the force and torque of which the musculature and bone structure of their young arms are not yet strong enough to withstand. See documentary, "America's Newest Arms Race," HBO Real Sports with Bryant Gumbel, aired April 2005.
} 
Dewey reminds us, "The wise mother takes account of the needs of the infant but not in a way which dispenses with her own responsibility for regulating the objective conditions under which the needs are satisfied." ${ }^{27}$ This concern for regulation suggests an important criterion according to which we determine whether instruction is beneficial to the child's development, because it is within the caregiver's power to regulate the objective conditions that will "influence directly the experience of others and thereby [place] upon him the duty of determining that environment which will interact with the existing capacities and needs of those taught to create a worth-while experience." ${ }^{28}$

Furthermore, Dewey suggests that it is by succeeding at certain tasks that we progressively hone in on, fine-tune, and reshape our dispositions - experience growth - and thereby give new meaning to our subsequent experience. ${ }^{29}$ Habits are reshaped in the processes by which we learn something new what Dewey means when he equates the adaptation of habits with learning or growth. Dewey scholar Thomas Alexander describes this dynamic trait of a habit as part of a process of learning, whereby "the habit itself expands and grows as it tries to adapt to the new circumstances so that the domain of organized responses develops; a premonition of the growth of meaning in experience. ${ }^{30}$ Our habits form the axis around which the dance of learning revolves. Habit centers our experiences, providing our impulses a harbor from which to venture in new directions and a place to return with new information to be used once again in the continuous reshaping of experience and future impulse. ${ }^{31}$

Though Dewey is clearly supportive of the free expression of natural impulses, nevertheless they must be guided by intelligent purpose. Unguided impulse too easily turns to misguided energy, which may lead to negative, if not disastrous, results. The mistake of equating "freedom with immediate execution of impulses and desires," Dewey attributes to a "confusion of impulse with purpose. ${ }^{\prime 32}$ For Dewey, purpose implies intelligent direction of our impulses and desires, which in turn requires thoughtful action. Thinking checks our impulses and desires, until further understanding directs their energies toward some more enabling purpose or aim. As a result, "the intellectual anticipation, the idea of consequences, [blends] with desire and impulse

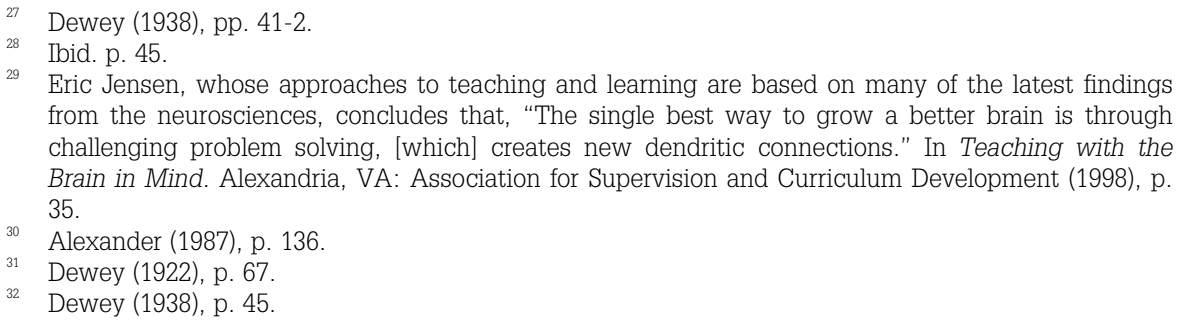
from the neurosciences, concludes that, "The single best way to grow a better brain is through challenging problem solving, [which] creates new dendritic connections." In Teaching with the Brain in Mind. Alexandria, VA: Association for Supervision and Curriculum Development (1998), p. 35.

${ }^{30}$ Alexander (1987), p. 136.

31 Dewey (1922), p. 67.

32 Dewey (1938), p. 45. 
to acquire moving force. It then gives direction to what otherwise is blind, while desire gives ideas impetus and momentum.." ${ }^{33}$

Meanwhile, helping a child understand that self-control realized in the process of thinking is not an affront to freedom, but rather that invoking thought is what one ought to do precisely in those moments when thought is most necessary - when we face the risks from allowing our blind impulses and desires to direct our actions - is an important step towards a self-directed life. Dewey suggests we use the energy from the child's impulses as the fuel that drives the engine of learning, as we steer these toward purpose, that is, toward intelligent action. Consequently, the child does not see her freedom opposed or thwarted, which then presents a further opportunity for her to view her own experience as appreciated and, therefore, meaningful.

If properly tended, the folds of experiential ambiguity give rise to order and solace, which together represent our rational and emotional efforts to navigate the dynamic interplay of learning - the give-and-take between freedom and control, impulse and habit, initiative and instruction, the playfulness with which life lessons are made palatable and the toughness and resilience with which they must be endured. The mistake of many parents and educators is found in the way in which they utilize outward freedom as license for the inchoate expressions of children's desires and impulses, rather than as an impetus for self-reflection on the purposes of their actions. Genuine freedom has to mean more. It has to mean action that is both intentionally guided by intelligent purpose and personally meaningful to the individual acting.

The most important, if not the most obvious reason for exercising such control comes from sheer necessity. It is an inevitable fact of our human condition that each of us must confront the challenges of life. We must then be as best prepared as possible to do what is within our power to bring about the highest quality of life possible. And, since ultimately all of us must do this for ourselves, our ability to do so must be properly formed. The individual most capable of exercising self-control, that is, of demonstrating self-discipline, is the one best suited to autonomously direct his or her life. Therefore, the task of educating children to direct their own lives is not only necessary for their continued existence, but also indispensable to the goal of achieving personal happiness.

Furthermore, and just as crucial, the consent by which we agree upon the goals or ends we deem appropriate for ourselves individually provides the very democratic basis by which we establish the rules or laws that circumscribe the realization of those goals or ends socially. Locke writes, "For law, in its true notion, is not so much the limitation as the direction of a free and intelligent agent to his proper interest, and prescribes no further than is for the general good of those under that law." In other words, accepting self-rule means

33 Ibid. 
that the establishment of law and social order is not a matter of imposition from an authority emanating beyond our selves for, as Locke goes on to say in the same passage, "the end of law is not to abolish or restrain but to preserve and enlarge freedom." 34

This idea is not much different from that later developed in Immanuel Kant's attempt to reconcile the readily held opposition between duty and personal fulfillment. In his formulation of the third practical principle of morality the principle of autonomy (the first refers to the universality of moral law, while the second relates to the recognition of all rational beings as ends in themselves) - Kant proposes it is our ability to rationally self-legislate or selfimpose moral laws, which ultimately binds us to universal moral laws. Kant writes,

According to this principle all maxims are rejected which are not consistent with the will's own legislation of universal law. The will is thus not merely subject to the law but is subject to the law in such a way that it must be regarded also as legislating for itself and only on this account as being subject to the law (of which it can regard itself as the author). ${ }^{35}$

It is Kant's hope that we recognize the very basis of morality lies in our ability to unite that which reason informs us is in our best interest with that which we are obligated to do. Therefore, obligations need not be construed as burdens, limitations, or impediments to free activity, but rather as what we rationally will for our own fulfillment.

What, then, constitutes the education of the democratic citizen? It includes, minimally, honing the individual's capability to rationally direct his or her own life, and to do so with full autonomy-as a self-directing individual who is able to define and realize his or her own goals. At the same time, the liberty with which one directs one's actions must in certain respects be kept in check, so as to render one's liberty and autonomy amenable to concerns for the social welfare of one's society. This requires from an early age a continuous and dynamic balance between self-control and the autonomy and free expression of the individual. So much of Locke's educational philosophy rests on striking this balance that he refers to its achievement as the "true secret" and "great art" of education. ${ }^{36}$ Notice that for Locke this relationship between our freedom and self-control is only a "seeming" contradiction. For to exercise our reason for the purpose of guiding action means simply engaging in a process of thinking according to which we ascertain the possible ramifications of

\footnotetext{
Locke (1952), p. 32.

Kant (1981), Section 431, p. 38.

Locke writes: "To avoid the danger that is on either hand is the great art; and he that has found a way how to keep up a child's spirit easy, active, and free, and yet at the same time to restrain him from many things he has a mind to, and to draw him to those things that are uneasy to him; he, I say, that knows how to reconcile these seeming contradictions, has, in my opinion, got the true secret of education." (Op. cit., 1947), pp. 237-8.
} 
bringing our impulses and desires to fruition. In turn, this allows us to accomplish two important ends: one benefiting us individually, the other socially.

First, the ability to exercise control over one's impulses and desires means that one does not become a slave to these. After all, not all desires are equally worthy. Though pursuit of some may be beneficial, the pursuit of others may oftentimes lead to our demise. A basic problem we seem to have in exercising self-control has much to do with our very conception of it as an opposition to freedom. An age-old and still prevalent misconception identifies freedom with license - the ability to do as we please regardless of any other consideration, and doing all that we desire to do for the simple reason that we desire to do it. Contrary to what an individual holding such a view of freedom may believe, this does not make us free. Rather, it makes us less free. By unquestioningly following our desires we become slaves to those very desires, since we thereby allow these to dictate our lives. We think ourselves free, yet we are not in control of our lives because we lack self-control.

Secondly, the more we exercise self-control, which necessarily entails at least a provisional suspension of our immediate impulses, interests, or desires, the greater chance that we are able to make the kinds of decisions that take into account the needs and interests of others. Ideally, others may be led to carry out the same process, which ultimately is beneficial to us all. Dewey, writing on the role of schools in bringing about social progress, echoes Locke's sentiments when he states "the art of thus giving shape to human powers and adapting them to social service, is the supreme art. ${ }^{\prime \prime 3}$ Douglas Simpson spells out the nuances of Dewey's contention, which, along with certain "powers" also requires a penchant for selflessness. He writes:

Dewey's particular interpretation of education is that it is vitally related to adapting human abilities for social service. Students need to develop a view of life that helps them get beyond personal interests and consider the interests of others. Their developed abilities, perceptions, and sensitivities should be adapted to meet the needs of society, including promoting a culture that takes into consideration the importance of people living democratically. ${ }^{38}$

Thus, in accordance with the exigencies of a democratic social vision, limitations must be placed upon individuals' pursuit of desire for desire's sake, all the while respecting the individual's autonomy.

This is not to imply that desires are in and of themselves detrimental to the achievement of democracy. Rather, democracy simply requires that individuals be discerning when it comes to that which is desired. With an air of Aristotelianism, Locke reminds us that specifically with children "the having of desires accommodated to the apprehensions and relish of those several ages, is not the fault; but the not having them subject to the rules and restraints of

\footnotetext{
37 Dewey (1897), p. 94.

38 Simpson (2005), p. 21.
} 
reason: the difference lies not in having or not having appetites, but in the power to govern, and deny ourselves in them." ${ }^{39}$ In other words, it is not desires that in and of themselves cause problems for human action; rather it is the unintelligent expression they are allowed that wreaks havoc on our affairs and makes us no different than the brutes. Exercising reason to contend with this effect provides us with greater opportunities for making the kinds of decisions that increase both our personal freedom and our chances for achieving an amicable and prosperous social existence.

As the vital instrument by which we arrive at self-discipline, according to Locke, one's ability to reason must be trained and developed as early as possible. But children's curiosities must be kept in check, hence the need for a continuous balance between freedom and control. At first, owing to their sheer lack of experience, habits to be developed in children must be firmly guided by the reasoning and example of adults. Unfortunately, being under the tutelage of adults is no guarantee against more harm being caused than good, as is the case with parents who indulge their children by either allowing their curiosities to go unchecked (over-permissiveness) or vigorously restricting these at every turn (over-protectionism). These two expressions of overindulgence on the part of parents and teachers, together work to absolve the child of any need to think on his or her own and undermine the deliberative process.

\section{Conclusion}

Although children ought to be respected, it is almost certainly true that due to sheer inexperience they simply lack the capabilities necessary to make adequate sense of their circumstances. For Locke, the parent who remains focused on the goal of discipline, even when required to deploy stern measures, in effect demonstrates a greater concern for the child's interest and welfare than the parent who spoils. ${ }^{40}$ Instead of recognizing the importance of the

\footnotetext{
Locke (1947), p. 231.

Although critical of regular and excessive corporal punishment (CP), Locke is not entirely opposed to its use; in particular when unruliness compromises the goal of discipline and the development of the child's autonomy. At the same time, Locke holds firm to the belief that "great severity of punishment does but very little good, nay, great harm in education; and that those children who have been most chastised, seldom make the best men" (Op. cit., 1947), pp. 236-7. Murray A. Straus \& Denise A. Donnelly, echo Locke's intuitions with the aid of empirical studies. The authors find that approximately ninety-percent of parents use some form of corporal punishment (CP) on toddlers. CP is defined as the use of physical force with the intention of inflicting or causing pain, but not injury, for the purposes of correction and control. Although a common rationale for CP revolves around efforts to curb anti-social behavior, there is evidence that it actually increases the likelihood of antisocial behavior at a later age. Toddlers who are spanked are more likely to be aggressive with their kindergarten peers. CP experienced during adolescence is associated with an increased likelihood of approving violence against one's spouse or siblings, experiencing depression as an adult, elevating levels of marital conflict, physical assault on other adults, physical abuse of children, masochistic sexual behavior, and alienation. See, Murray A. Straus \& Denise A. Donnelly, Beating the Devil
} 
end, parents focus on the means literally at hand, and give in to their children's whims and impulses or crush any semblance of their autonomy. By this very concession, parents themselves become poor examples of self-discipline and initiative, respectively. Furthermore, neither form of overindulgence gets us any closer to achieving democracy according to its minimal criteria of autonomy and a spirit of social cooperation.

In their dealings with the everyday obstacles, frustrations, and challenges before them, children must be allowed the freedom to learn from the consequences of both their successes and failures. Tough lessons to learn and lessons that require toughness to teach are valuable lessons parents and teachers today all too often run from, by doing everything they can to avoid even the slightest hint of conflict, frustration, or pain. ${ }^{41}$ Rousseau suggests we allow natural consequences to do their part, make their impact, and have their effect. Incidentally, the freedom and playfulness that characterize Rousseau's oft-misunderstood pedagogy require a complementary habit of resilience with which to face life's more arduous and painful lessons. Yet, exploratory play is more frequently missing from the new arenas of childhood, where games are highly structured, supervised, and even professionalized to the point where personal gratification becomes irrelevant. ${ }^{42}$ Missing from these more technically sophisticated forms of play are opportunities for children to hone the skills needed for resolving their own conflicts and disputes, not to mention lost opportunities to earn a sense of personal achievement, as more and more parents live vicariously through their children's play.

It is imperative to the pursuit of happiness that children perceive their lessons as necessary to their own development - lessons that seem to flow from and lead naturally toward the satisfaction of their real needs. But to satisfy children's needs does not mean that their desires and supplications ought to be overindulged. Parents who spoil their children surreptitiously undermine their autonomy by overriding it, which is tantamount to imposing upon them the severest of restrictions on their freedom to do as they see fit for themselves. As we have seen, by freedom, philosophers of education throughout the modern period do not intend the vulgarity of opportunism we commonly mistake as indulgence. Rather, they intend the freedom that allows children to

Out of Them: Corporal Punishment in American Families and Its Effects on Children. Somerset, NJ: Transactions Pub. [1994] (2001).

${ }^{41}$ According to Alfie Kohn, conflict is perceived by teachers as a kind of "dandruff" - "something unsightly to be eliminated as rapidly as possible." Alfie Kohn, Beyond Discipline: From Compliance to Community. Alexandria, VA: ASCD (1996), p.75. Kohn suggests, we are missing the point that "the conflict is the lesson," adding that, "To discourage (let alone punish) objections is to sacrifice the development of judgment to the imperative of conformity" (Ibid. p.76).

42 We have gone as far as "criminalizing play," author Richard Louv concludes in his Last Child in the Woods: Saving Our Children from Nature-Deficit Disorder. Chapel Hill: Algonquin Books (2005). Also, Brooke Adams reports on the "real costs for children" of being kept from play: "diminished use of senses, attention difficulties and higher rates of physical and emotional illness." In "Go Play Outside," The Salt Lake Tribune (http://www.sltrib.com) retrieved June 13, 2005. 
explore their impulses in order to discover and properly gauge the requirements of their own needs and interests, as well as their own in relation to the wellbeing of others.

Rousseau's Emile, for instance, learns to "count on himself alone" and is in possession of "a precise and unprejudiced mind; he is satisfied, happy, and free." ${ }^{43}$ Emile is independent and self-sufficient, and steadfast in those decisions that help ensure his wellbeing. Having been made free first by being taught to yield to necessity, he never loses sight of what it means to be his own person-a freedom he carries in his heart and thus "takes with him everywhere." ${ }^{44}$ Emile's upbringing is the basis and backdrop of his happiness.

When we think of child abuse, we think of physical, psychological, and emotional harm brought deliberately upon a child. Such harm is typically thought to have the effect of impairing or incapacitating the child's development - of somehow enfeebling the child's potential. The possibility of happiness and, dare I say, a democratic form of life, requires of us a kind of rational and emotional dexterity and acumen that helps establish the very conditions for personal empowerment necessary in our pursuit of such a way of life. The deliberate distraction from the development of these requisite powers constitutes, I believe, a disguised form of child abuse.

\section{Bibliography}

Alexander, Thomas. John Dewey's Theory of Art, Experience, and Nature: The Horizons of Feeling. Albany: State University of New York Press, 1987.

De Botton, Alain. Status Anxiety. New York: Random House Inc., 2004.

Dewey, John. "My Pedagogic Creed" (1897). EW5: 84-95. All references to John Dewey are from (ed.) Jo Ann Boydston. The Collected Works of John Dewey, 1882-1952. Carbondale and Edwardsville: Southern Illinois University Press, 1969-1991. The Early Works: 1882-1898 (EW), The Middle Works: 1899-1924 (MW), and The Late Works: 1925-1953 (LW), followed by specific volume and page numbers. . and Evelyn Dewey. The Schools of Tomorrow (1915). MW8: 205-408. . Human Nature and Conduct: An Introduction to Social Psychology (1922). MW 14. . Experience and Education (1938). LW 13: 1-62.

Kant, Immanuel. Grounding for the Metaphysics of Morals [1785]. Indianapolis: Hackett Publishing Co., 1981.

Locke, John. Some Thoughts Concerning Education [1693], in John Locke on Politics and Education. Roslyn, NY: Walter J. Black Inc., 1947.

. The Second Treatise on Civil Government. Indianapolis: Bobbs-Merrill Co. Inc., [1690] 1952.

Plato, Republic, (trans) Paul Shorey, in Plato: The Collected Dialogues. (eds.) Edith Hamilton and Huntington Cairns. Princeton: Princeton University Press, [1961] 1994.

\footnotetext{
$43 \quad$ Rousseau (1979), p. 208.

44 Ibid. p. 473.
} 
Rousseau, Jean-Jacques. Discours sur l'Origenes et le Fondements de l'Inegalite Parmi les Hommes [1755], Lester G. Crocker (ed.), translated by anonymous (1761) as Discourse on the Origin and Foundation of Inequality Among Men. New York: Washington Square Press, 1967.

. Emile ou De l'Education [1762], Allan Bloom (trans) Emile or On Education. New York: Basic Books Inc., 1979.

Simpson, Douglas. "John Dewey's View of the Teacher as Artist," 2001 Mary Anne Raywid Lecture sponsored by The Society of Professors of Education. Cf. John Dewey and the Art of Teaching. Thousand Oaks, CA: Sage Publications, 2005. 